\title{
Between Yesterday and Today: Contemporary Art in Nepal
}

\author{
Kathryn Hagy
}

\begin{abstract}
This paper examines works from the last decade by six Nepalese artists and delves into questions such as how today's artists align themselves between their ancient arts and their contemporary context. What is the conversation about globalism and its impact on artists? How do artists deal with social pressures and is the content of their work directly affected by these pressures? Through in-country research and subsequent study and interviews with artists, what is revealed is an energetic art scene that draws much of its inspiration from a local context, whether that be affirmation of or protest against that context to some degree. When visiting Kathmandu Nepal, one is bound to discover that like the ancient sculptures, paintings and temple architecture that exist on every corner, the art of contemporary Nepal is everywhere as well.
\end{abstract}

Keywords: Kathmandu; Nepal; contemporary; art; artivism; globalism

When visiting Kathmandu, one is bound to discover that, like the ancient sculptures, paintings and temple architecture that exist on every corner, the art of contemporary Nepal is everywhere. Especially in Kathmandu, one senses the same artistic energy of cities like New York and Berlin. New artists function as educators and arts administrators and their protégés benefit from the "artivism"1 activities of their mentors. Art installations and performances spring up in Kathmandu Valley public squares utilized by both residents and tourists for practical and religious purposes. Today's performance art and installation is another aspect of pilgrimage and ritual within sacred space. Social upheavals and desperation for change shape the processes, materials, subject, and content of art in contemporary Nepal.

Globalism's effect on the booming art production and markets of India and China cannot be denied, and both countries are benefiting from the interest of local, expatriate, and western collectors. But what of the smaller countries surrounding India and China, such as Nepal? I began to think about Nepal's physical, economic, and artistic quandary while preparing for a Fulbright Fellowship in Kathmandu in 2010. There is a great deal of literature on the historical arts of the Malla and Licchavi periods and increasingly more on the arts of midcentury that depart from traditional modes. However, I found very little scholarly information on art of the immediate present-my area of interest—because much scholarship on Nepalese culture privileges the arts of the past over what is produced now. I wondered how today's artists aligned themselves between their country's ancient arts and their contemporary context. What is the conversation about globalism and its impact on artists? How do artists deal with social pressures and is the content of their work directly affected by these pressures?
Kathryn Hagy is a professional artist with a Master's degree in Painting and Printmaking from Rhode Island School of Design. In 2010, Hagy was the recipient of a Fulbright Scholarship for research in Kathmandu, Nepal where she taught art, developed her artwork related to water images, and researched contemporary Nepalese art. 
Though the Nepalese themselves acknowledge the cultural connections between their country and India and China, it is important to note that many Nepalese bristle while talking or writing about these connections, or about relationships with regions such as the West. In a survey of Nepali art from medieval to modern, scholar Abhi Subedi states that, "Extensive studies of Nepali art in various books and survey articles by different scholars have shown the uniqueness of Nepali art, especially in relation to Indian art of a similar vein in the Eastern monasteries of India. Still, many scholars and observers tend to ignore the uniqueness of early Nepali art and draw hasty conclusions about the extension of Indian influences on it."' Subedi may have read noted scholar of Nepalese studies Michael Hutt's 1994 Guide to the Art and Architecture of the Kathmandu Valley in which Hutt contends that "Contemporary [Nepali] artists are beginning to develop a school of painting that is both modern and distinctly Nepali. Nevertheless, the great masterpieces of Nepali art belong firmly to the past...." As one can imagine, these type of sentiments are met with dismay among today's Nepalese artists. The modernism to which Hutt refers came about through the return of a foreign-educated Nepalese artist named Lain Singh Bangdel (1919-2002), who studied in India during the 1940s and later emigrated to Paris where he associated with artists such as Pablo Picasso and Georges Braque.

In 1961, the King of Nepal pressed Bangdel to return and in the following year he exhibited his works within his country for the first time, marking the beginning of the modern period and becoming the father of modernism in Nepal. ${ }^{4}$ What Kathmandu viewers saw for

Figure 1: Lain Singh Bangdel, Reflection, 2000, oil on canvas, $30 \times 24$ inches. Image courtesy of Dina Bangdel

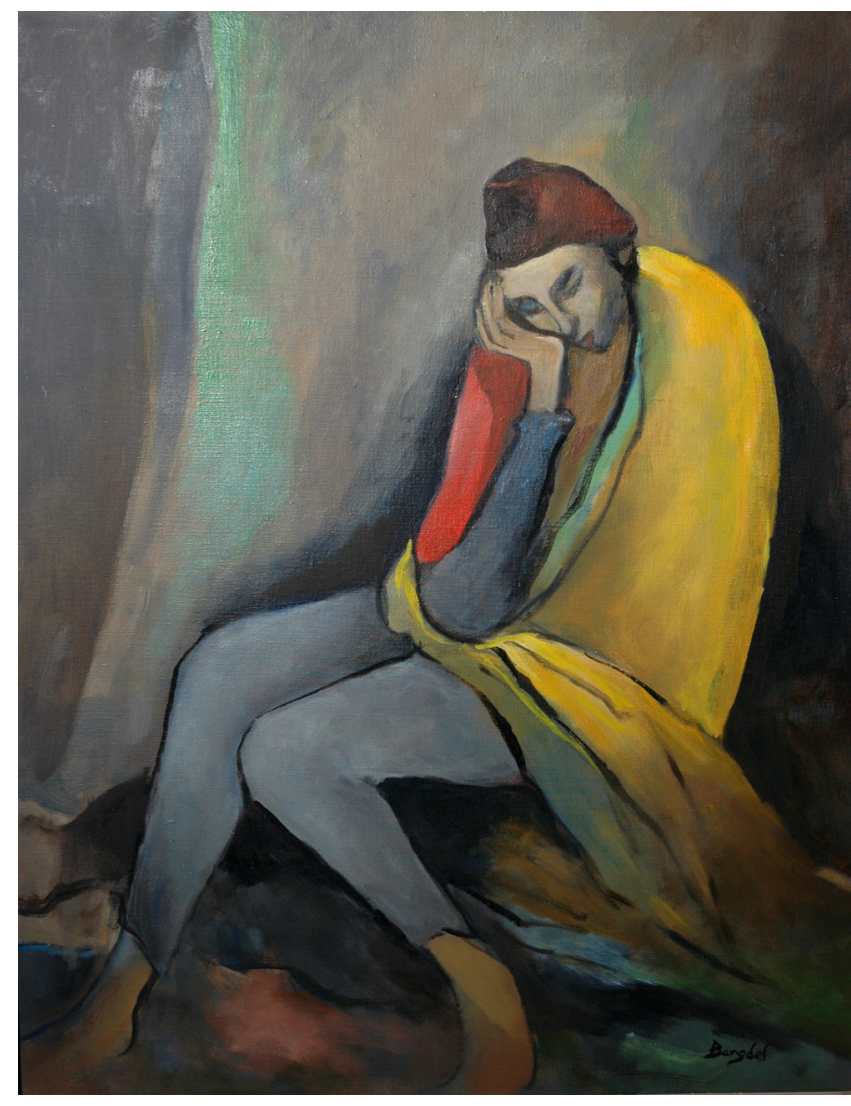
the first time was what one reporter called the "unique presentation of human drama." ${ }^{5}$ One can see the influence of both Picasso's Blue period in Bangdel's work (Figure 1) and other works employ abstract expressionist tendencies.

Nepalese artists continued studying abroad, most notably in India and Bangladesh, where western educational systems still exerted a presence in the post-colonial era. ${ }^{6}$ Bangdel's election to head the Royal Nepal Academy in the 1970s had a great impact on younger artists and art educators. What he and others like him accomplished was to bring western approaches, processes, and art media to Nepal. Western cultural tastes had already

been established in Nepal under the rule of the Ranas during the late nineteenth and early twentieth centuries, and court artists had turned "away from a mythic-religiously motivated [concept] toward works of art that served the ends of personal uplift and thus possessed a 
purely aesthetic character."' In Bangdel's work, one can see abstraction, expressionism, and the traditional western genres of portraiture over cultural motifs.

In a lecture on "Hybridity and Negotiation in Contemporary Nepali Painting," scholar Yam Prasad Sharma summarized these cultural motifs as magical, mystical, narrative, didactic, anthropomorphic, exhibiting religious harmony, meditation/concentration, union of self/cosmos, and resolving differences between the sacred and profane. ${ }^{8}$ In this Three Mother Goddesses paubha painting (Figure 2), we can see the mysticism of meditating and floating gods, including the anthropomorphic Ganesh, above an earthly narrative. In the contemporary sculpture of

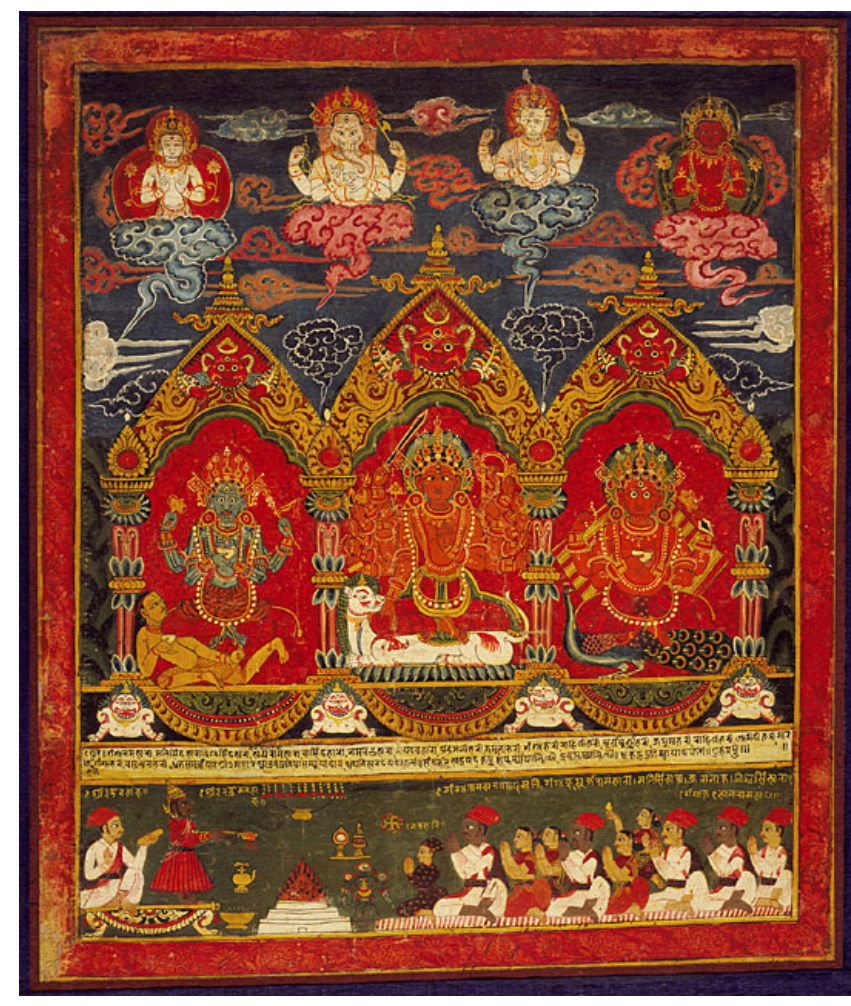
Laya Mainali, his primary subject is the Shiva linga as the resolution of sacred and profane. His bronze yoni suggests an absent linga that is further emphasized by the title Mother and Child (Figure 3).

According to Subedi, “....the most important feature of modern Nepali art is that the artist is divided between rejection and acceptance of tradition - its values and techniques. In some very well-known paintings, the tension itself is the subject matter of the painting." The work of Shashikala Tiwari is a good example of this (Figure 5). Her flower and figurative forms derive from nature, yet the swirling energy of the paintings nearly breaks the figure and flowers apart, or at least has caught these forms in inescapable eddies. The painting's tone, expressed through color and form, isn't dangerous but tense. The petal forms come to knife points

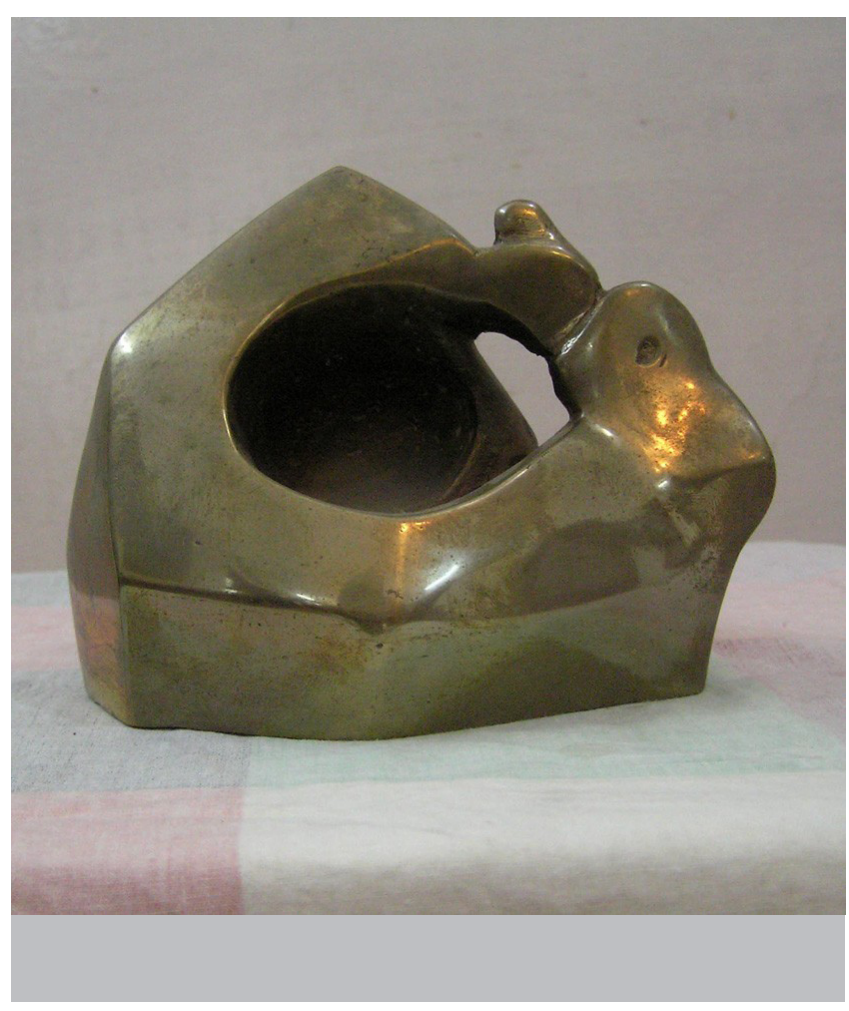

Figure 2: Three Mother Goddesses (Matrikas): Chamunda (left), Mahalakshmi (middle), Kaumari (right), 1679, Pata/Paubha painting, opaque watercolor on cloth, from Bhaktapur Nepal, 23 $1 / 2 \times 19$ 3/4"

Figure 3: Laya Mainali, Mother \& Child, 2000-03, bronze, 5 × 6 inches. Image courtesy of the artist; Bottom: Shiva Linga at Pashupati Temple, Kathmandu, Nepal 
Figure 4: Shiva lingum in one of the Pandra Shivalaya shrines at Pashupatinath Temple, Kathmandu. Image courtesy of the author.

Figure 5: Shashikala Tiwari, Mystery Morning (alternate title: Sun Behind the Spiderweb), 1998, oil on canvas, 34 x 37 inches. Image courtesy of the artist.

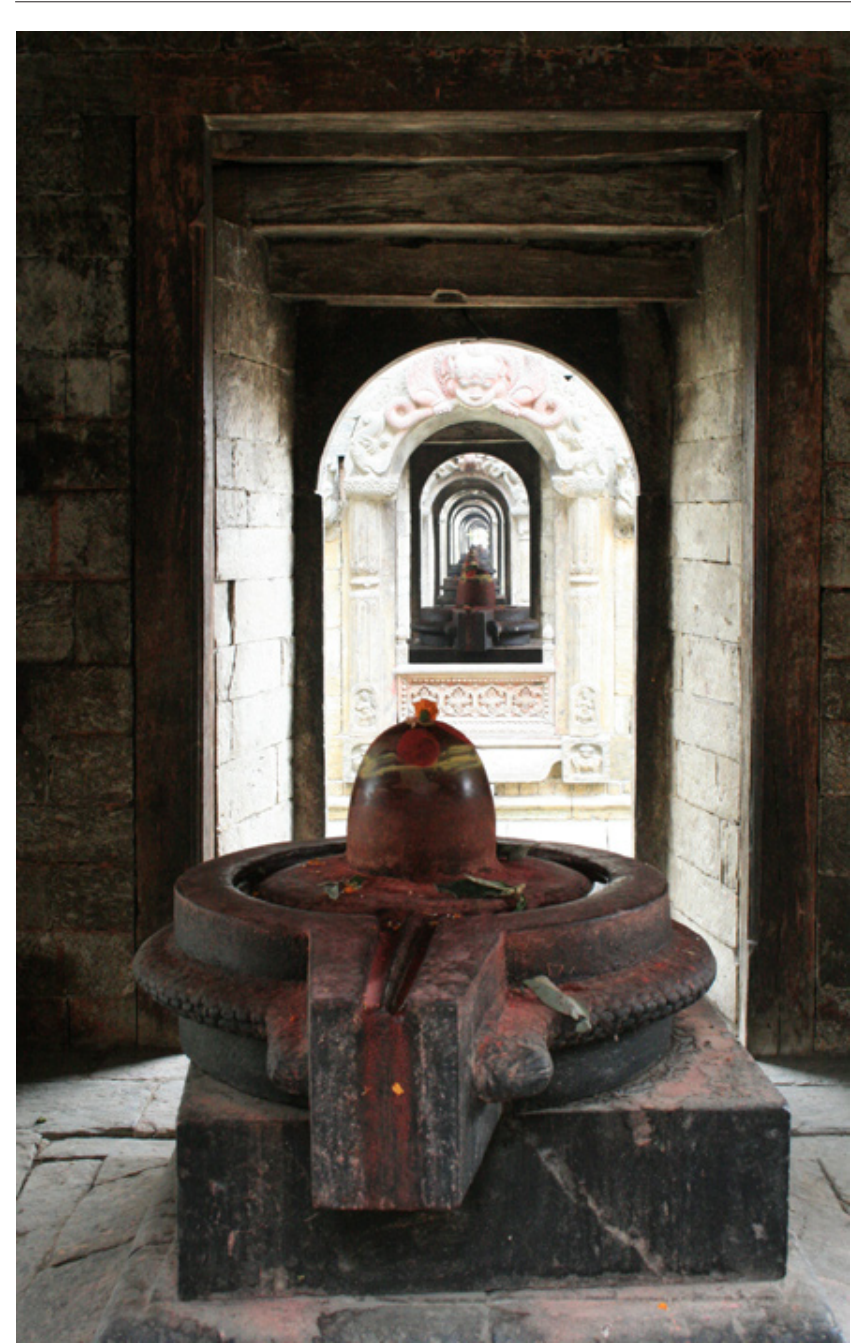

but are just soft enough to balance their jaggedness. Tiwari states that her "paintings depict the troubled, tortured, and exploited female figures in the patriarchal society through the use of mythical characters..." from Buddhist and Hindu traditions. ${ }^{10}$ Certainly Tiwari deals with the specific tensions facing women in Nepali society as a subject, but she does so by using traditional stories and figures in order to question traditional valuesboth accepting and rejecting tradition simultaneously. The artist's identity as a woman is important because of the generally second-class status of women in Nepal, and the work is edgier for it. Tiwari's paintings are a product of their local milieu and engage with western techniques of abstraction and expressionism via Lain Singh Bangdel.

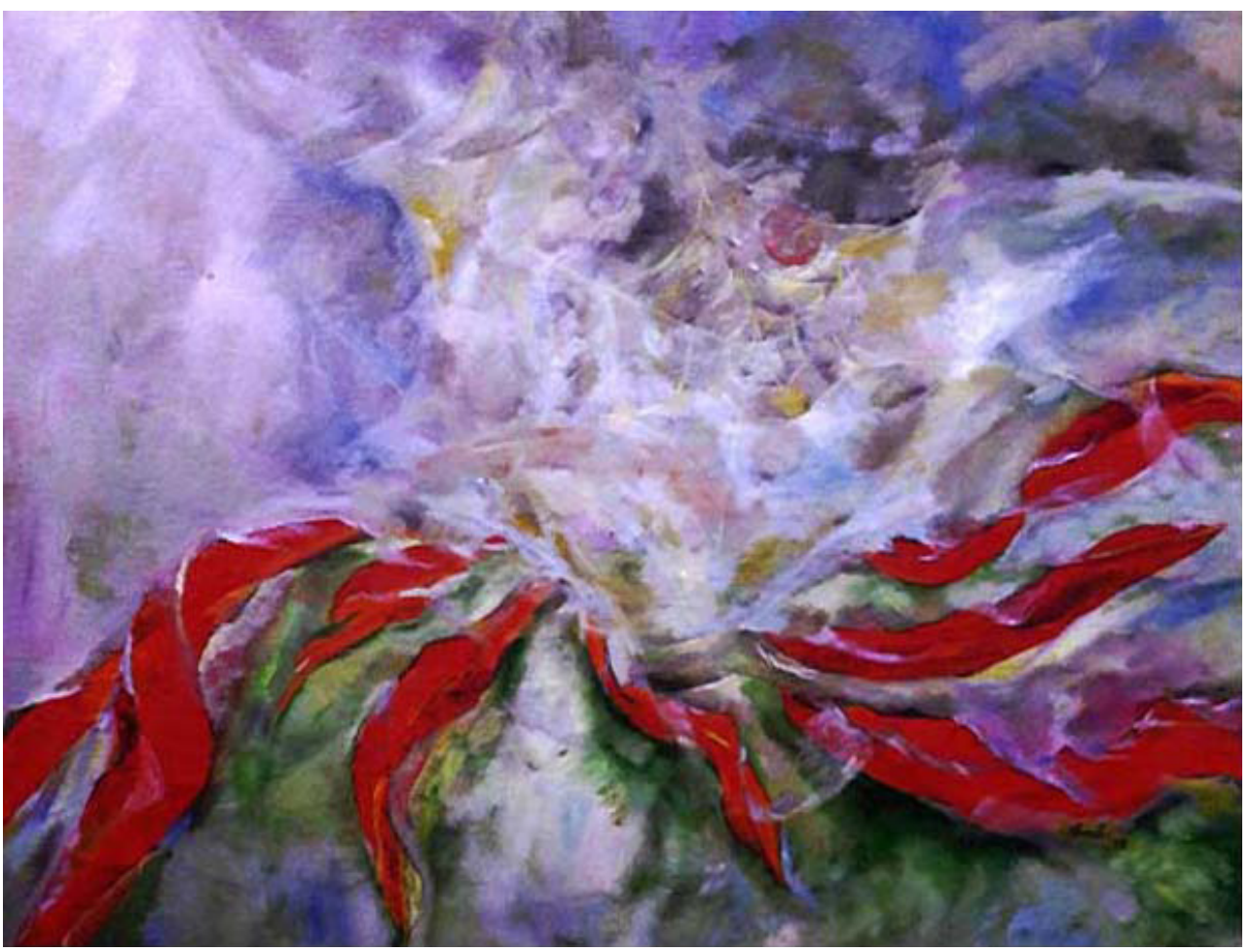

33 Between Yesterday and Today: Contemporary Art in Nepal 
Another challenge facing Nepalese artists relates to abstraction and expressionism's former avant-garde status in the modern period of western art. But -isms don't have the same effect in other contexts. As if to heed Geeta Kapur's call for those in developing countries to examine their own history and experiences in order to locate and define the modern, ${ }^{11}$ one raging topic of debate in Nepali art circles concerns how one defines the words modernism, modernity, and contemporary in Nepal, and whether these terms even apply to Nepal's art and culture. A growing but still contested definition of the contemporary in Nepal would include art with sociopolitical content and exclude artworks created today that are concerned with formal over conceptual qualities, as well as artworks in experimental media, such as performance and installation, outside of the socio-political context. The discussions are healthy but paralyzing at the same time because many feel they must contend with these issues. Tiwari's works are contemporary because an artist working today painted them within the last few years. Based on the above definition, they would also be contemporary because of the latent feminist message. However, her works reference the late modern period in the West and the new modern period in Nepal. But many Nepalese debate the beginnings of a modern period within their country due to the radical social and political transformations over the last twenty years. Countries like India seem to have dealt with these questions as part of a postcolonial dialogue. Nepal was never physically colonized by a western power but due to its strong connection to India there is a feeling of cultural colonization by both the West and its neighbors India and China.

Another debate that emerges from this anxiety is whether Nepali art should reflect an innate Nepaliness. A series of international art camps in the 1990s encouraged collaboration among artists in South and Central Asian countries like Sri Lanka, Pakistan, India, Nepal, and Bangladesh, and brought to the foreground some of these authenticity and identity issues. One participant from a 1997 camp remarked that, "We still maintain that Oriental east-west dichotomy in visual arts. Today, the West still considers the art of South Asia as fairly exotic...." ${ }^{12}$ This same sentiment is expressed by many Nepalese artists today. A further expression of the east-west dichotomy is a distrust of new media such as installation and performance, because these are perceived as western postmodernism even in a country where elaborate "installations" in the form of religious shrines have existed for centuries.

Debates about national identity are extremely important as Nepal's ethnic and caste tensions have only recently calmed after the Maoist insurgency, and the country was shocked by the 2001 massacre of the royal family.

Part of this feeling of the exoticized or culturally colonized Nepal stems from a frustration with the country's tourist image. While Nepal is proud of its artistic heritage, contemporary artist Ashmina Ranjit and other Nepalese cultural critics question what they see as the packaging and selling of heritage and the effect this has on artists in particular. According to Ranjit, whose work I will discuss in this paper, "Nepal has long been marketing itself as a Shangri-la and abode of medieval art and artifacts from the Licchavi and Malla periods-without recognition of contemporary life and cultures." ${ }^{13}$ Many in the arts are trying to foster a deeper knowledge and appreciation of Nepal's artistic past. With the founding of her arts organization Lasanaa in 2007, Ashmina Ranjit organizes workshops and events to use art as a catalyst for change within society. This activism within art has caught on and in the last few years alone, a number of new arts organizations, galleries, and performance spaces have been founded, and international collaborations have occurred.

One such collaboration, through a 2011 Arts Network Asia (ANA) grant, involves leading art students and emerging artists on heritage walks in Kathmandu Valley to foster this deeper cultural knowledge beyond the marketed "myth" of Nepal. For example, as mechani- 
Figure 6: Dhara with water spouts in Handigaon, Kathmandu. Image courtesy of the author.

cal engineer and social entrepreneur Anil Chitrakar leads these heritage walks through Kathmandu Valley, he frames Kathmandu's famed heritage with questions meant to engage participants to critically reflect on connections between past and present, tradition and change. In some cases, this search for depth is quite literal. One such walk through the old squares of Bhaktapur took an interdisciplinary approach to the architecture of water basins, known in Nepali as dharas (or hitis in the Newari language). Many of these water sources are now dry or only have flowing water for limited periods (Figure 6). The spouts of these dharas are frequently carved in the shape of mythical or symbolic creatures such as nagas or water serpents with water flowing from their open mouths. These spouts are wonderfully

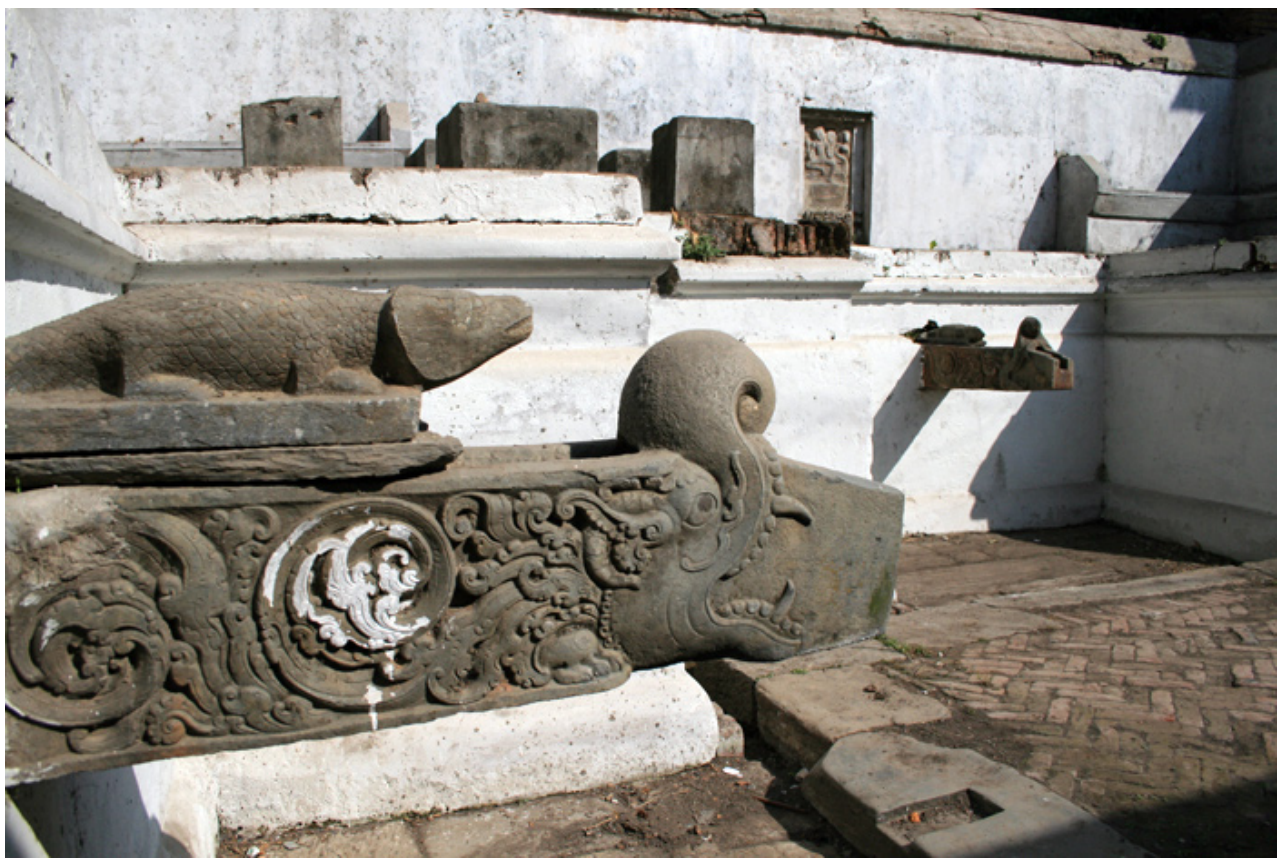

monstrous and one also sees reproductions throughout Kathmandu-in five-star hotels or at the entrance to Pashupatinath Temple for Hindu worshippers. Anil Chitrakar goes beyond the symbolic imagery to livability. In one of his tours recorded on YouTube he says, "The question is not just being able to look at the monuments and the houses and the way of life, but you have to take care of the watershed behind you." ${ }^{14}$ His talk goes on to explain the mechanics and engineering behind these historical water delivery systems and why many are nearly dry, showing the effects of modern development, political controls, and societal change.

In asking Anil Chitrakar to lead these Kathmandu Valley tours for art students and emerging artists, Ashmina Ranjit hopes they will see their history's art and architecture with fresh eyes, revealing the hand Nepalese artists and creative thinkers have long had in shaping their society. As part of the ANA grant, heritage walk participants conducted research in their own localities, interacting with citizens and field experts before creating new artworks. This is one way Nepalese artists examine their own history and experiences in order to define their presentness visually.

Today many artists openly deal with sociopolitical issues. At the same time, rather than feature what Subedi calls the "rejection and acceptance of tradition," these artists seek an acceptance of, and departure from tradition toward, works that are both local and global. Though by no means defining, a few general qualities of contemporary Nepali art include 
reinterpretation of religious stories and rituals, subversion of established icons, ambivalence toward cultural traditions and/or the West, multimedia or multigenre approaches, and integration of images and forms from nature. Each of the following artists utilizes these qualities in their work.

The artist Ashmina Ranjit received her art training in Australia and the United States but returned to Nepal during a time when Nepali artists, influenced by the international arts camp experiences, were beginning to experiment with new genres such as installation and performance. This is notable because in 1993, Nepal's Association of Fine Arts had rejected installations as unacceptable art forms. The violence of the Maoist insurgency and the royal murders dredged up raw emotions and seemed to call for art forms that could engage the public and initiate healing dialogue. In addition, artists like Ranjit wanted to challenge conventional art forms such as painting and sculpture. Her works "are designed to increase awareness of crucial ongoing

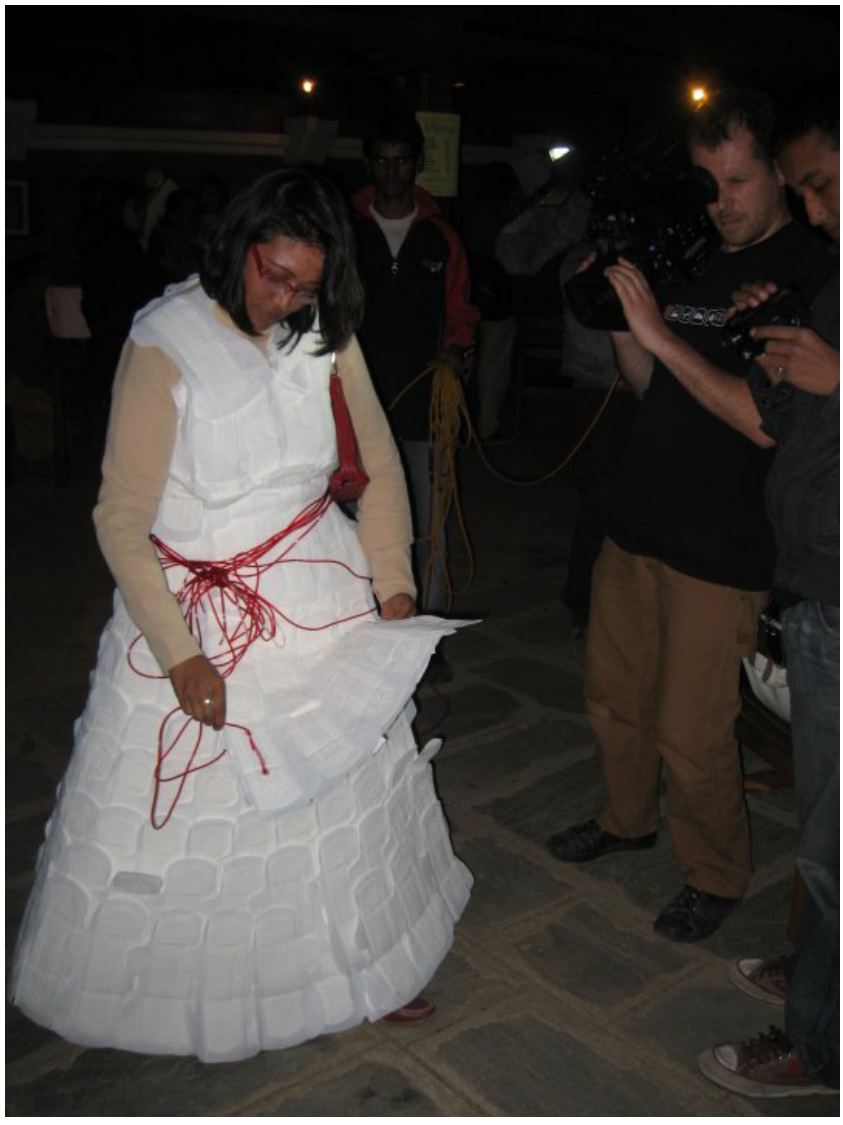
social and political issues of marginalized communities."15 In Feminine Force (Figure 7), she uses performance to express ambivalence toward the Hindu belief in the impurity of women's bodily fluids, especially menstrual blood. As she walks through the surrounding market areas of Kathmandu's Basantapur Square in her dress made from sanitary pads, she infringes upon the mental space of traditional Nepalese citizens and forces a visceral reaction. The piece draws from the western feminist artworks of the 1970s in its confrontation with women's lives, but does so within Nepal's cultural context. Ranjit is a controversial figure in Nepal but she feels that her tactics are necessary for change.

Because biotourism and cultural tourism are the greatest contributors to Nepal's economy, Kathmandu's 2010 "Planet Nepal Festival” was an artist's response to another big issue - the environment. Festival artists created films, installations, and performances of all kinds during this three-day exhibit and conference. In this second work, Ranjit transformed the courtyard of the Patan Museum where many of the conference panels took place (Figure 8). She wove mats using traditional materials and processes. Attendees were invited to sit on the mats, harmonize their relationships with nature, and imagine alternatives to "the daily rituals of synthetic modernity." ${ }^{16}$ Ranjit combines the more recent genre of installation with traditional materials and processes to reconnect audiences to their "authentic" spiritual sources, while at the same time subtlety critiquing the "synthetic" lifestyles of the West. ${ }^{17}$
Figure 7: Ashmina Ranjit, Feminine Force, 2010 performance for International Women's Day in Basantapur Square, Kathmandu. Dress made out of sanitary towels (the number of sanitary pads in the dress equals the average periods that a woman has in her lifetime -33 years $\times 13$ months $x 4$ days $=8,580$ pads). Image courtesy of the artist. 
Figure 8: Ashmina Ranjit, Indigenous Modernities, 2010, installation of woven straw from the "Planet Nepal" Festival at the Patan Museum in Kathmandu, sponsored by Alliance Francaise.
In Figure 9, Asha Dangol uses what he considers the free association techniques of the Surrealists to create paintings that reinterpret the folk arts of the Mithila ethnic groups, in which horses are prominent, or the Newar ethnic group. ${ }^{18}$ Dangol, too, is a founding member of an artist collective known as Kasthamandap Art Studio, named after the building from which the city of Kathmandu takes it names. His New Age Chariot could be a reference

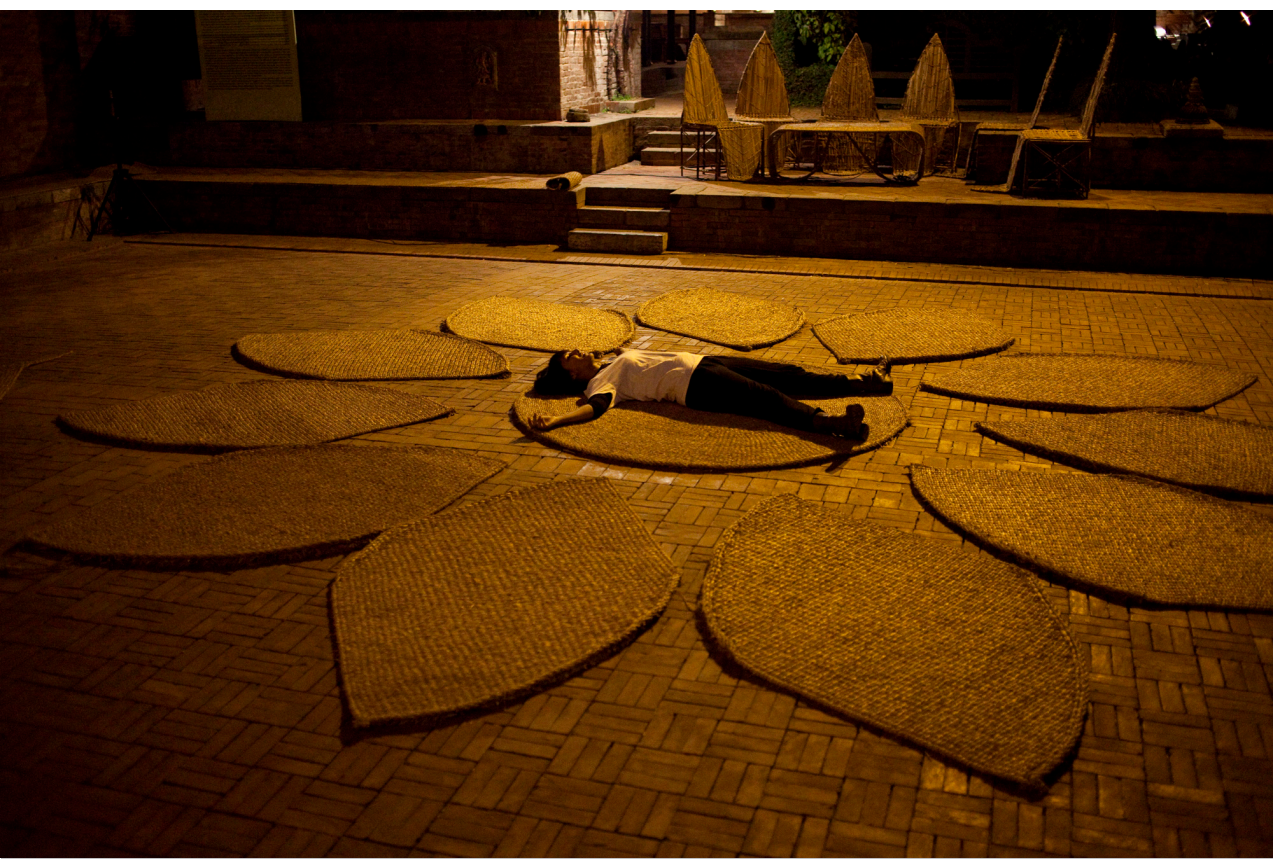

to the Newari Bisket Jatra festival, the New Year's celebration of the ancient Kathmandu Valley city of Bhaktapur. However, because the iconography diverges from Bisket Jatra, the artist is creating new meaning. This spring festival celebrates triumph over evil and re-enacts a creation story involving the God Bhairav and Goddess Bhadrakali, each of whom is pulled

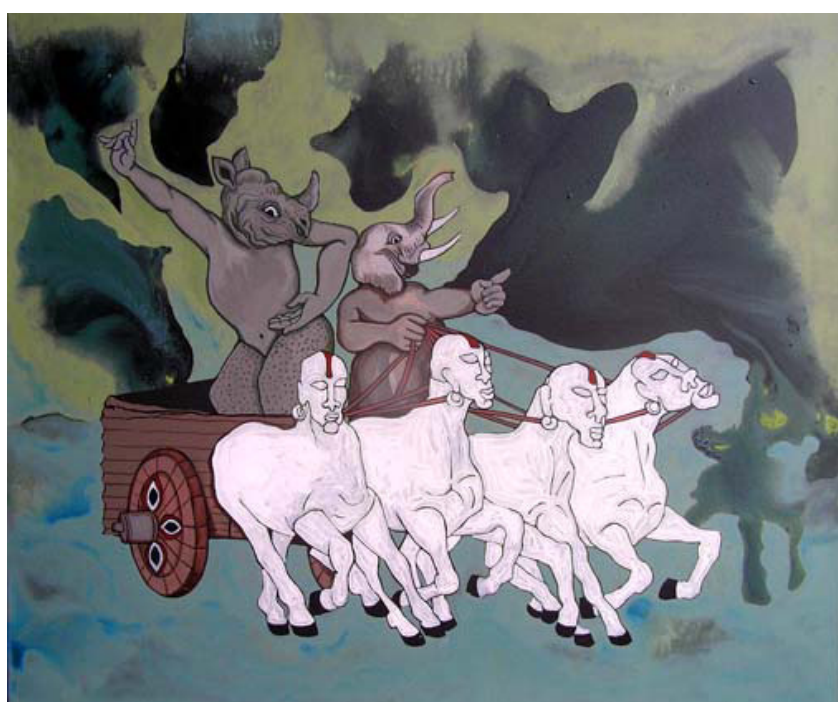
in their respective chariots. The public participates in an exciting (and sometimes dangerous) chariot pull and tug-of-war and spends the next nine days revering not only Bhairav and Bhadrakali, but a number of other Gods who ride in smaller chariots through the streets of Bhaktapur. ${ }^{19}$ The Newar pantheon also includes an elephant-headed God that may be one of the figures depicted in Dangol's chariot, and perhaps he paints those

Gods of significance to him and his family. If he is in fact using Surrealist automatism, these figures may have been randomly chosen in order to represent Bisket Jatra's essence over any particular ritual or day within the nine-day festival. The expressionless and seemingly sightless anthropomorphic horses in opposition to the eyed Gods, and the high contrasting 
stormy shapes in the background, give the dreamy Surrealism a nightmarish quality that may convey the tumultuous annual chariot pull. However, there is also joy in the dancelike posture of the rhinoceros-headed figure at left. Dangol acknowledges a departure from tradition in his artist statement, yet there is no outright rejection of tradition, as we shall see in his next work.

Only one-and-a-half years after Ashmina Ranjit's public performance condemning belief in the impurity of women's menstrual blood, Ashutosh Tiwari of the nongovernmental organization WaterAid called for artists to submit responses to Chaupadi, or the forced isolation of women during menstruation or after childbirth. The resulting exhibit, entitled "Dropping in on Development," lasted one evening in the Hotel Himalaya, a five-star hotel in Kathmandu, and was one of two events highlighting the effect that menstruation taboos have on development. Tiwari explains that, "We do not want women to drop out of schools, to drop out of jobs, to drop out of society for a few days every month, to drop out from having good health...we want them to drop in. ${ }^{20}$ Asha Dangol was one of the ten mostly male artists chosen to exhibit works. It is unclear whether the predominance of male responses to this topic was intended for greater impact, but the gender ratio was specifically noted in at least one local newspaper review following the exhibit reception. ${ }^{21}$

In Dangol's Menstruation - the Symbol of Purity (Figure 10), he uses the lotus blossom's symbol of purity to alter Hindu perceptions of women's impurity. While lotus flowers are an important symbol in Hinduism, Buddhism, and Jainism, the context clearly references the Hindu concept of pure beauty originating from the filth of muddy waters. In commenting about the installation's symbolic communication, the artist states that, "The flow of blood and breaking of the uterus lining is a process of cleansing." 22

Similar to the lotus sprouting from Vishnu's navel, in Dangol's piece a female mannequin's vaginal region sprouts long red veins blossoming into lotus flowers. The life of women is further accentuated by the
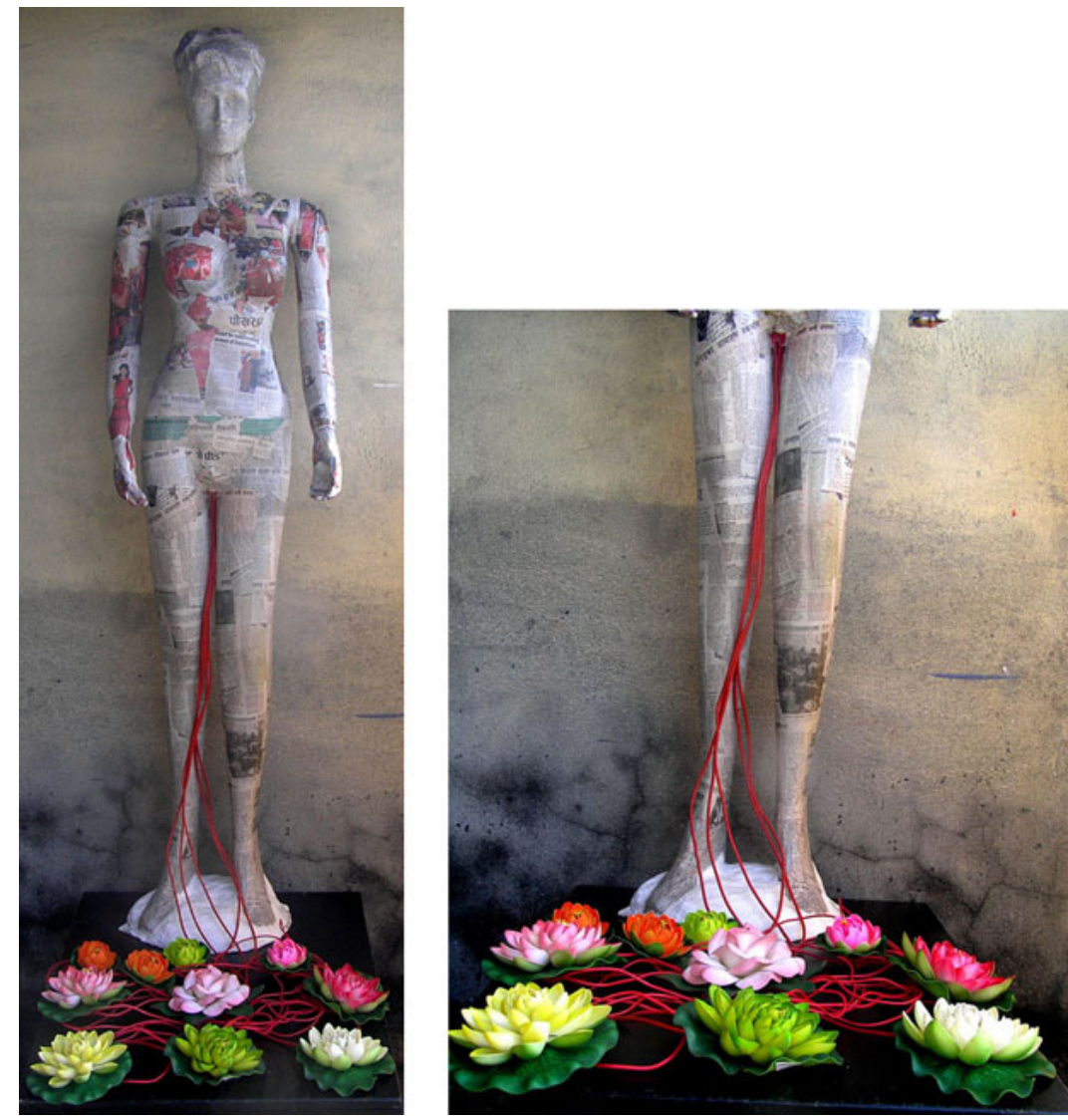
newspaper clippings coating the mannequin, featuring images and stories of women, most notably
Figure 10: Asha Dangol, Menstruation - the Symbol of Purity, 2011, mixed media installation as part of the "Dropping in on Development" exhibit sponsored by WaterAid at the Hotel Himalaya, Kathmandu. Images courtesy of the artist. 
photographs from the previous month's Teej festival. Teej represents many positive things for Nepalese women, but the aspect of purification of body and soul to exonerate sins from the previous year is closely connected with Dangol's intentions to affirm purity by recontextualizing it.

Asha Dangol's installation and the exhibit as a whole aim at a very different audience than Ashmina Ranjit's Feminine Force public performance in a city square. The "Dropping in on Development" exhibit sponsor WaterAid is not an arts organization and the event was held in a five-star hotel, so the exhibit was likely aimed at changing perceptions of ministers and other high-level attendees in a position to effect change. The resulting press would likely be the only widespread public outreach. However, this type of collaboration between artists and other members of society is one of the resurfacing trends in Kathmandu that, as mentioned in my discussion of Anil Chitrakar's heritage talks for emerging artists, may draw upon the traditional involvement of Kathmandu Valley artisans in the shaping of daily life.

Artist Sujan Chitrakar belongs to the painting caste of Chitrakars famous for documenting Nepal's daily urban life. Like Lain Singh Bangdel and Ashmina Ranjit, Chitrakar also received advanced degrees abroad (specifically in India) but returned to Nepal to advance his country's contemporary art practices by mentoring young artists through his role as the program coordinator for the Centre for Art and Design at Kathmandu University. His choice to become a conceptual artist over the painting tradition of his caste may seem like a radical departure, but the Chitrakar family painters have always dealt with the urban landscape as subject matter.

Figure 11: Sujan Chitrakar, Rickshaw Project, 2010, mixed media mobile artwork, from the "Planet Nepal" Festival at the Patan Museum in Kathmandu, sponsored by Alliance Francaise. Images courtesy of the artist.

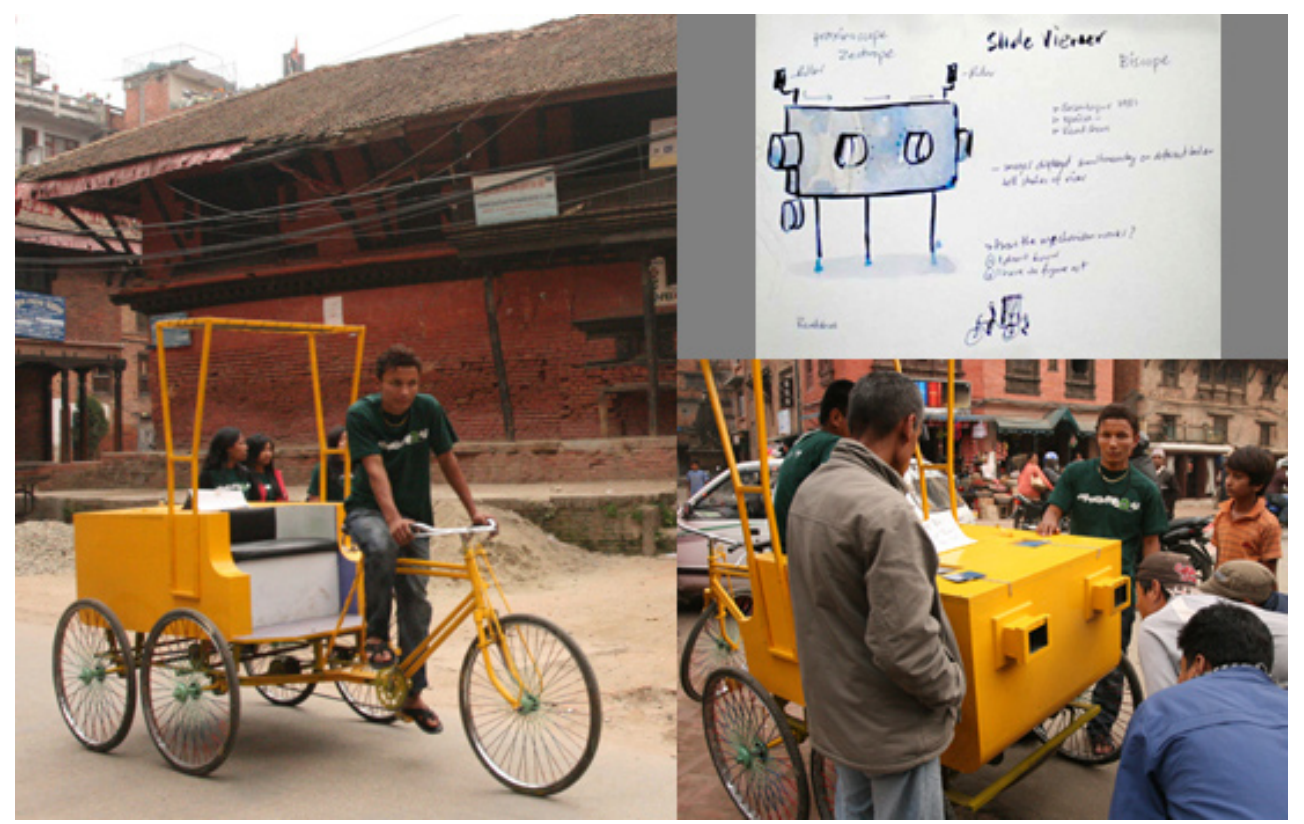

In his Rickshaw Project (Figure 11), Chitrakar embraces the protean tendencies of contemporary conceptual artists and diverges from painting into sculpture and installation, repackaging the age-old rickshaw as an environmentally friendly means of transport and a mobile art piece through the urban landscape. ${ }^{23}$ In this way, Chitrakar updates the traditions of family caste. Depicted here is just one of several rickshaw transformations that circled the city during the festival, bringing awareness to a public that may have taken these vehicles for granted in the push to modernize toward gas-guzzling vehicles. Like Ranjit, 
Chitrakar is critical of those who play it safe and he pushes his students and art public to question their traditions by engaging with art in new ways. ${ }^{24}$ Whether intended or not, Chitrakar's Rickshaw Project pokes fun at his audience because the vehicle for delivering meaning is literally a vehicle, and one powered by human effort.

For Nepal, the question of national identity comes from an unfortunately violent recent past but all facets of the society are getting a fresh start. Today's Nepal isn't afraid to reexamine its own past and contemporary life for content, forms, materials, and processes. Arguments still rage about authenticity and work that should be strictly "Nepalese" without derivation from any source. Others recognize that cultural hybridization has always occurred and they embrace globalization and are not waiting for the world to come to them. In grappling with questions of identity, the paralysis that may seem to prevent Nepalese artists from making a mark soon gives way as artists do what they have always done and solve problems through the creative process. For example, debates about whether installation and performance artforms are too foreign for Nepal don't take into consideration the religious "installations" or shrines on nearly every corner and the "performance art" that worshippers engage in during daily ritual at these shrines or spaces that are both public and private. How contemporary artists align themselves between ancient and modern, tradition and change is becoming less binary and more fluid. The lively and growing art scene in Nepal and especially Kathmandu is what makes it possible for artists such as Asha Dangol and Ashmina Ranjit to challenge traditional beliefs about menstruation in very different ways, and to hit nerves by creating works that mirror aspects of their society.

\section{NOTES}

1. Artivism is a term combining art and activism, used to describe art activities that actively engage in political and social dialogues as a way to alter the discourse and outcome.

2. Abhi Subedi, "Nepali Art: Nepali Utopia," Contributions to Nepalese Studies 22, no. 2 (July 1995): 115.

3. Michael Hutt, Nepal: A Guide to the Art and Architecture of the Kathmandu Valley (Boston: Shambhala Publications, Inc., 1994), 29.

4. Don Messerschmidt and Dina Bangdel, Against the Current: The Life of Lain Singh Bangdel_Writer, Painter and Art Historian of Nepal (Bangkok: Orchid Press, 2004), ix-x.

5. Subedi, "Nepali Art: Nepali Utopia," 124.

6. Ibid., 124 .

7. Susanne van der Heide, “Traditional Art in Upheaval: The Development of Modern Contemporary Art in Nepal," Kailash-Journal of Himalayan Studies 14, nos. 3 \& 4 (1988): 234.

8. Yam Prasad Sharma, "Contemporary Nepali Painting: Hybridity and Negotiation" (Art Discussion Series, Martin Chautari, Kathmandu, August 31, 2010).

9. Subedi, "Nepali Art: Nepali Utopia," 125.

10.E-Arts Nepal. "Shashikala Tiwari Biography”, http://www.eartsnepal.com/artist/shashikala-tiwari.htm

11.Geeta Kapur, "When Was Modernism in Indian Art?” in When Was Modernism: Essays on Contemporary Cultural Practice in India, ed. Geeta Kapur (New Delhi: Tulika Books, 2007), 298.

12.Sabine Grosser, "Contextualizing Contemporary Sri Lankan Art," in Expressions of Independence (Paris: Mona Bismarck Foundation, 2008), 67.

13. Ashmina Ranjit to Arts Network Asia, "Being in Kathmandu Valley," project statement, October-November 2010.

14.MsSGV, Anil Chitrakar's Bhaktapur Walk: Water (video), July 31, 2009. http://www.youtube.com/ watch?v=tRXeurcl_rE\&feature=related.

15. Ashmina Ranjit, "Environment Friendly Environment" in Alliance Bazaar Special Edition: Festival of Arts and Environment (Kathmandu: Alliance Francaise, September-October 2010), 10.

16. Ashmina Ranjit, "Environment Friendly Environment," 10.

17. Ashmina Ranjit, "Environment Friendly Environment," 10.

18.E-Arts Nepal. "Asha Dangol Biography," http://www.eartsnepal.com/artist/asha-dangol.htm

19. This is an extremely brief summary of Bhaktapur's nine-day Bisket Jatra festival, but necessary to give context for Asha Dangol's work. For more on this important Newar festival, see http://66.7.193.115:8080/kathmandumetro/culture/bisket-jatra-the-festival-of-dead-serpents-1

20. WaterAid Nepal Site. "News: Dropping in on development: an exhibition," http://nepal.wateraid.org/news item/63-dropping-in-on-development-an-exhibition

21. Republica. "The Art of Menstruation," review of Dropping in on Development, October 1, 2011. http://www. myrepublica.com/portal/index.php?action=news_details\&news_id=36737. 
22. Asha Dangol, "Dropping in on Development," e-mail message to author, November 22, 2011.

23. "Rickshaw Project, in Alliance Bazaar Special Edition: Festival of Arts and Environment (Kathmandu: Alliance Francaise, September-October 2010), 11.

24.Sujan Chitrakar, Let's Talk about ART Baby! (Exhibit Catalog) (Kathmandu, Nepal: Sujan Chitrakar and Siddhartha Art Gallery, 2010) 6. From an interview with the artist conducted by Pranab Man Singh. 